\title{
Meningkatkan Kemampuan Guru dalam Melaksanakan Pembelajaran yang Efektif Menggunakan Model Pembelajaran Problem Based Instruction melalui Kelompok Kerja Guru (KKG)
}

\section{Ida Ayu Nyoman Juli Puspareni*}

SD Negeri 5 Bedulu, Gianyar, Indonesia

\author{
A R T I C L E I N F O \\ Article history: \\ Received 19 August 2020 \\ Received in revised form \\ 30 September 2020 \\ Accepted 10 October 2020 \\ Available online 29 \\ November 2020

\section{Kata Kunci:} \\ Kemampuan Guru, Model \\ Pembelajaran Problem \\ Based Instruction, \\ Kelompok Kerja Guru \\ (KKG) \\ Keywords: \\ Teacher Ability, Problem \\ Based Instruction Learning \\ Model, Teacher Working \\ Group
}

mengalami peningkatan m kelompok kerja guru (KKG).

A B S T R A K

Penelitian Tindakan Sekolah yang dilakukan ini bertujuan untuk meningkatkan kemampuan guru dalam melaksanakan proses pembelajaran yang efektif di SD melalui pelaksanaan pembelajaran problem-based instruction melalui kelompok kerja guru (KKG). Data hasil penelitian ini dikumpulkan dengan cara melakukan supevisi dengan instrumen. Dalam menganalisis data yang diperoleh digunakan metode analisis deskriptif. Data yang dihasilkan dari penelitian ini terdiri dari data awal, data siklus I dan data Siklus II. Dari data awal diperoleh rata-rata kemampuan melaksanakan proses pembelajaran yang efektif, hanya mencapai nilai 74,88 dan ketuntasan baru mencapai $33,33 \%$. Data ini jauh di bawah harapan mengingat ketuntasan pelaksanaan proses pembelajaran minimal 90,00. Rata-rata nilai siklus I sudah terjadi peningkatan yaitu rata-ratanya mencapai 81,11 dan prosentase ketuntasannya mencapai $66,66 \%$. Pada siklus II perolehan rata-ratanya sudah mencapai 89,55 dan persentase ketuntasan sudah mencapai 100\%. Data pada Siklus II ini sudah sesuai harapan, yaitu kemampuan guru dalam melaksanakan proses pembelajaran yang efektif di SD enggunakan model pembelajaran problem-based instruction melalui A B S T R A C T

This school action research was conducted to improve the ability of teachers to carry out an effective learning process at SD Negeri 5 Bedulu in the first semester of the 2019/2020 academic year through the implementation of problem-based learning through teacher working groups (KKG). The research data were collected by supplying the instrument. In analyzing the data obtained using descriptive analysis method. The data generated from this study consisted of initial data, cycle I data and cycle II data. From the preliminary data, it was obtained that the average ability to carry out an effective learning process only reached a value of 74.88 and a new completeness reached $33.33 \%$. This data is far below expectations considering that the completeness of the learning process is at least 90.00. The average value of the first cycle has increased, reaching 81.11 and the percentage of completeness has reached $66.66 \%$. In the second cycle the average score has reached 89.55 and the proportion of completeness has reached $100 \%$. The data in Cycle II was as expected, namely the ability of teachers to carry out an effective learning process at SD Negeri 5 Bedulu in the first semester of the 2019/2020 academic year, which increased using a problem-based learning model through teacher working groups (KKG). 


\section{Pendahuluan}

Kepala sekolah dan guru juga merupakan komponen yang memegang peranan dalam bidang pendidikan. Keberhasilan pendidikan lebih banyak ditentukan oleh kemampuan guru dalam melaksanakan tugasnya (Pohan, 2017) akan tetap keberhasilan tersebut tidak terepas dari kerja sama dan interasi yang baik dengan kepala sekolah. Kepala sekolah adalah pemegang kunci keberhasilan keberlangsungan pendidikan di sekolah yang dipimpinya (Ekosiswoyo, 2016; Ramadoni \& Arifin, 2016). Tugas utama seorang kepala sekolah adalah mengawasi dan sekaligus meningkatkan kemampuan guru dalam melaksanakan proses pembelajaran. Sebagai kepala sekolah harus betul-betul memperhatikan apakah pembelajaran itu berkualitas atau tidak, apabila tidak berkualitas maka hal tersebut akan berbahaya terhadap mutu pendidikan (Muhani et al., 2016). Seperti yang terjadi saat ini mutu pendiidkan indonesia menjadi sorotan yang tajam. Rndahnya mutu pendidan ini tidak terlepas dari proses pembejaran yang dilakukan.

Cara pembelajaran guru yang terus-menerus menggunakan model pembelajaran konvensional harus segera diakhiri, sudah berkembang begitu pesat dan maju. Kebiasaan guru mengajar dengan sistem lama harus segera mendapat penanganan oleh kepala sekolah. Guru-guru harus berupaya melakukan pembelajaran menggunakan model-model pembelajaran yang didasari teori-teori yang benar. Tidak terbantahkan lagi bahwa kepala sekolah harus mampu meningkatkan kemampuan guru melaksanakan proses pembelajaran. Tugas kepala sekolah dalam hal ini adalah tugas wajib untuk memeri bimbingan kepada semua guru, sehingga penelitian yang dilakukan bisa saja sama dalam meningkatkan proses pembelajaran namun pada subjek dan tempat yang berbeda.

Kelemahan-kelemahan di lapangan selama proses pembelajran yang dilakukan di SD Negeri 5 Bedulu pada semester I tahun pelajaran 2019/2020 yang menyebabkan rendahnya kemampuan guru dalam melaksanakan proses pembelajaran yang efektif, tidak sepenuhnya disebabkan oleh faktor luar seperti kesibukan guru, keadaan rumah tangga, lingkungan dan lain-lain. Kelemahan-kelemahan yang ada banyak pula dipengaruhi oleh faktor dari dalam guru itu sendiri seperti kemauan menyiapkan bahan yang lebih baik, kemauan menyiapkan media-media pembelajaran yang menarik. Semua uraian di atas menunjukkan hal-hal yang perlu dilakukan dalam upaya meningkatkan kemampuan guru melaksanakan proses pembelajaran problem based instruction melalui kelompok kerja guru (KKG). Apabila betul-betul guru menguasai dan mengerti tentang hal-hal tersebut dapat diyakini bahwa kemampuan guru dalam proses pembelajaran bisa ditingkatkan. Namun kenyataannya kemampuan guru dalam melaksanakan proses pembelajaran yang efektif di SD Negeri 5 Bedulu hanya mencapai rata-rata 74,88 dengan kualifikasi C (cukup) yaitu ketuntasan guru hanya mencapai 33,33\%. Hal ini sangat jauh dari indikator keberhasilan yang mengharapkan kualifikasi A (amat baik) dengan rentang nilai dari 86-100. Pembelajaran di sekolah akan sangat efektif apabila guru melaksanakannya dengan memahami peran, fungsi dan kegunaan mata pelajaran yang diajarnya. Di samping pemahaman akan hal-hal tersebut keefektipan itu juga ditentukan oleh kemampuan guru untuk merubah paradigma pengajaran menjadi pembelajaran.

Melihat kesenjangan antara harapan-harapan yang telah disampaikan dengan kenyataan lapangan sangat jauh berbeda, dalam upaya memperbaiki mutu pendidikan sangat perlu kiranya dilakukan perbaikan cara pembelajaran. Salah satunya adalah perbaikan pembelajaran dengan pelaksanaan pembelajaran problem based instruction melalui kelompok kerja guru (KKG) Sebagai upaya untuk meningkatkan kemampuan guru dalam melaksanakan proses pembelajaran yang efektif. Oleh karenanya penelitian ini sangat penting untuk dilaksanakan. Meurut (Listiowati, 2013) Pembelajaran berbasis masalah atau Problem Based Instruction dikembangkan untuk membantu siswa mengembangkan kemampuan berpikir, pemecahan masalah, keterampilan intelektual, dan belajar berbagai peran dengan dewasa melalui pelibatan mereka dalam pengalaman nyata atau simulasi, serta menjadi siswa yang otonom dan mandiri. Menurut (Prayekti, 2010) Problem Based Instructional (PBI) menjadi alternatif model pembelajaran yang dapat diterapkan guru dalam pembelajaran fisika di kelas yang dapat meningkatkan hasil belajar, aktivitas dan respon siswa dalam pembelajaran. Menurut Fujiah (2016) Dengan penerapan model pembelajaran PBI siswa lebih memahami konsep yang diajarkan, sebab mereka sendiri yang menemukan konsep tersebut dan melibatkan secara aktif pemecahan masalah dan menuntut keterampilan berpikir siswa yang lebih tinggi.

Penelitian yang dilakukan oleh (Komalasari \& Program, 2019) menyatakan bahwa pembelajaran menulis cerpen dengan menggunakan model PBI telah memenuhi kriteria keefektifan. Kemudian penelitian yang dilakukan oleh (Khanafiyah \& Yulianti, 2013) menyatakan bahwa pembelajaran fisika lingkungan yang dilaksanakan dengan model problem based instruction dapat meningkatkan sikap kepedulian lingkungan dan kemampuan mahasiswa dalam memecahkan masalah. Berdasarkan jabaran tersebut, dapat dirumuskan tujuan melaksanakan penelitian ini adalah untuk meningkatkan kemampuan guru dalam melaksanakan pembelajaran yang efektif di SD Negeri 5 Bedulu pada semester I tahun 
pelajaran 2019/2020 melalui pelaksanaan pembelajaran problem-based instruction melalui kelompok kerja guru (KKG).

\section{Metode}

Penelitian yang dilakukan di SD Negeri 5 Bedulu di harapkan mampu meningkatkan kemampuan gugu-guru dalam pelaksanaan proses pembelajaran. Penelitian tindakan ini terfokus pada penelitian tindakan sekolah.

Untuk penelitian ini penulis memilih rancangan penelitian tindakan yang disampaikan oleh Dave Ebbut seperti terlihat pada gambar berikut.

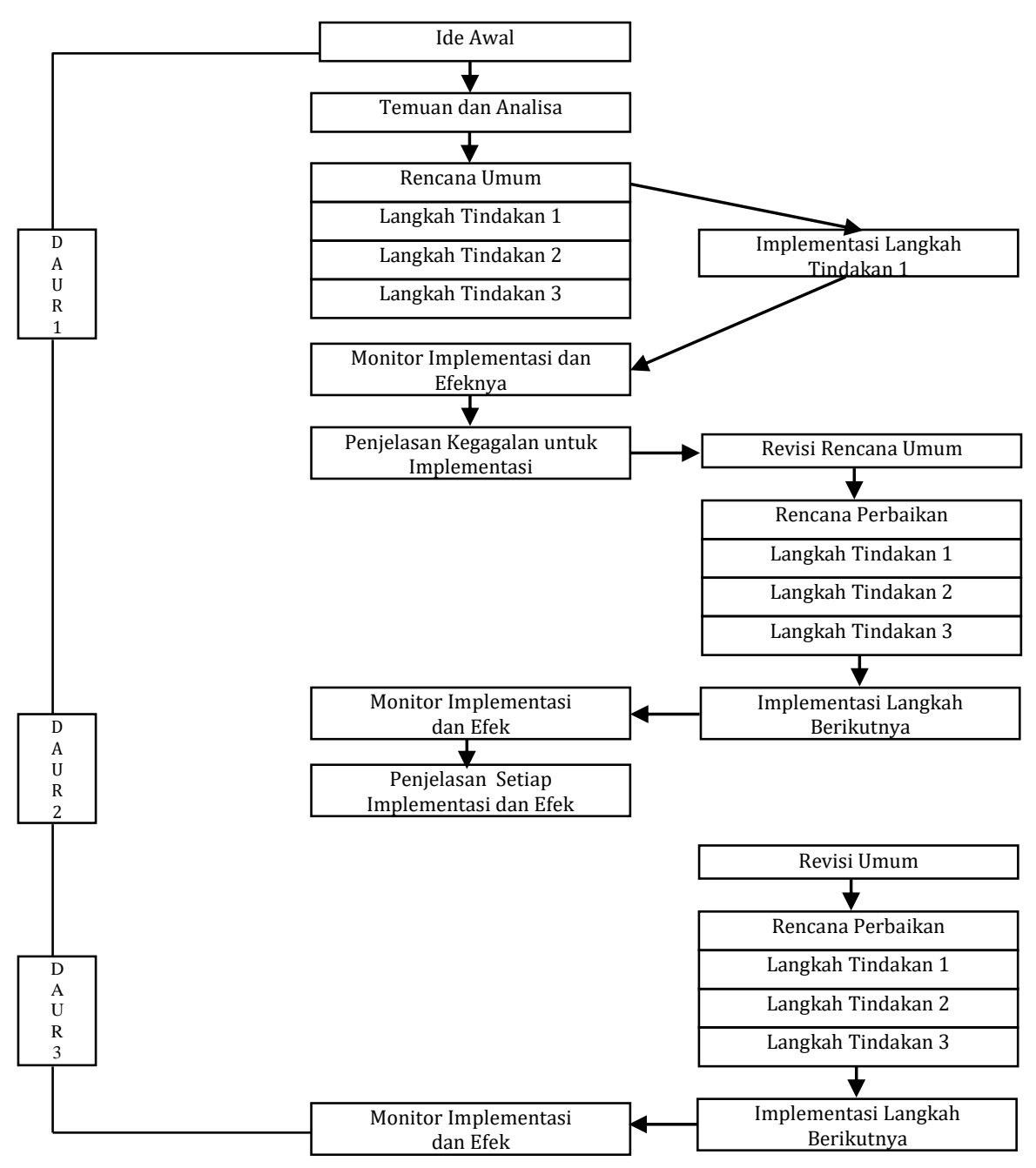

Gambar 1. Rancangan Penelitian Tindakan Model Ebbut (1985)

Berikut Prosedur sebagai alur PTK, Ebbut memberi contoh yaitu:

Pada daur I dimulai dengan adanya ide awal akibat temuan dan analisis yang telah dilakukan. Setelah ada temuan tersebut dibuatlah perencanaan umum sesuai langkah yang direncanakan baik tindakan 1, tindakan 2 maupun tindakan 3. Sesudah membuat perencanaan, diimplementasikan dalam tingkat 1, dimonitoring implementasinya serta efeknya kemudian dijelaskan kegagalan-kegagalan yang ada selama implementasinya lalu dibuat revisi umum untuk perencanaan tindakan selanjutnya.

Pada tindakan selanjutnya, perencanaan yang telah dibuat diimplementasikan, terus dimonitor implementasinya serta efek yang ada, dijelaskan setiap langkah implementasinya dan efeknya.

Setelah mengetahui bagaimana hasil dan efeknya, dibuat lagi perencanaan untuk tindakan selanjutnya. Demikian berlanjut sampai menemukan hasil yang sesuai tujuan yang direncanakan.

Subjek penelitian ini adalah guru-guru di SD Negeri 5 Bedulu dalam pelaksanaan proses pembelajaran semester I tahun pelajaran 2019/2020. Objek Penelitian ini adalah peningkatan 
kemampuan guru-guru dalam melaksanakan proses pembelajaran yang efektif melalui pelaksanaan pembelajaran Problem Based Instruction (PBI) melalui kelompok kerja guru (KKG).

Penelitian tindakan sekolah yang dilakukan ini sudah sudah terjadwal sedemikian rupa yaitu dari bulan Juli sampai bulan Dsember pada semester I tahun pelajaran 2019/2020. Kegiatannya termasuk perencanaan/pembuatan proposal pelaksanaan, observasi/pengambilan data dan refleksi.

Metode mengumpulkan data adalah observasi. Observasi adalah suatu teknik atau cara mengumpulkan data dengan jalan mengadakan pengamatan terhadap kegiatan yang sedang berlangsung, kegiatan tersebut bisa memberikan pengarahan, personil bidang kepegawaian yang sedang rapat, dsb (Nana Syaodih Sukmadinata, 2007: 220). Setelah kegiatan supervisi individual ini berlangsung dilakukan kegiatan supervisi seperti: diksusi, tanya jawab, unjuk kerja dan bersama-sama melakukan studi dokumen terhadap buku-buku pegangan guru. Hasil tanya jawab tidak dipaparkan karena hal tersebut merupakan langkah untuk memperkuat kemampuan guru-guru melaksanakan proses pembelajaran untuk menopang kegiatan nyata yang dilakukan. Unjuk kerja dilakukan dengan melakukan proses pembelajaran setelah mereka siap dengan perencanaan yang telah dibuat. Demikian rencana pengumpulan data yang penulis susun. Adapun data hasil penelitian ini yang dipergunakan dalam menganalisis adalah analisis deskriptif. Untuk menganalisis data hasil penelitian ini digunakan model analisis kuantitatif. Ini dilakukan karena data yang diperoleh berupa angka. Cara analisis yang direncanakan adalah mencari mean, median, modus, interval kelas, penyajian dalam bentuk tabel dan grafik. Yang penulis rencanakan ini hanya sebatas perhitungan yang gampang pada tingkat statistika dasar.

Instrumen dari penelitian ini adalah lembar observasi yang ada di masing-masing RPP. Indikator keberhasilan dari penelitian ini diusulkan pada siklus I dan siklus II mencapai nilai rata-rata 86 dengan kualifikasi A (Amat baik) yaitu antara 86-100. Dan ketuntasan pembelajaran yang diharapkan mencapai $80 \%$.

\section{Hasil dan Pembahasan}

Penelitian yang dilakukan di SD Negeri 5 Bedulu di harapkan mampu meningkatkan kemampuan gugu-guru dalam pelaksanaan proses pembelajaran. Penelitian tindakan ini terfokus pada penelitian tindakan sekolah. Berdasarkan hasi penelitian maka diperoleh bahwa terjadi peneingkatkan kempauan guru menggunakan model PBI melalui kelompok KKG, peningkatan hasil penelitian ini dapat dilihat pada tabel 01 dan gambar 01.

Tabel 1. Rekapitulasi Hasil Penelitian

\begin{tabular}{|c|c|c|c|c|c|c|c|c|c|}
\hline \multirow[b]{2}{*}{$\begin{array}{l}\text { No Subyek } \\
\text { Penelitian }\end{array}$} & \multicolumn{3}{|c|}{ Awal } & \multicolumn{3}{|c|}{ Siklus I } & & \multicolumn{2}{|c|}{ Siklus II } \\
\hline & $\begin{array}{l}\text { Perolehan } \\
\text { Skor }\end{array}$ & $\begin{array}{c}\text { Rata- } \\
\text { Rata }\end{array}$ & $\%$ & $\begin{array}{c}\text { Perole- } \\
\text { han } \\
\text { Skor }\end{array}$ & $\begin{array}{l}\text { Rata- } \\
\text { Rata }\end{array}$ & $\%$ & $\begin{array}{l}\text { Perolehan } \\
\text { Skor }\end{array}$ & $\begin{array}{c}\text { Rata- } \\
\text { Rata }\end{array}$ & $\%$ \\
\hline 1 & 40 & 80 & $40 \%$ & 46 & 92 & $46 \%$ & 47 & 94 & $7 \%$ \\
\hline 2 & 46 & 92 & $46 \%$ & 41 & 82 & $41 \%$ & 43 & 86 & $3 \%$ \\
\hline 3 & 38 & 76 & $38 \%$ & 46 & 92 & $46 \%$ & 47 & 94 & $7 \%$ \\
\hline 4 & 34 & 68 & $34 \%$ & 40 & 80 & $40 \%$ & 44 & 88 & $4 \%$ \\
\hline 5 & 38 & 76 & $38 \%$ & 39 & 78 & $39 \%$ & 45 & 90 & $5 \%$ \\
\hline 6 & 34 & 68 & $34 \%$ & 40 & 80 & $40 \%$ & 44 & 88 & $4 \%$ \\
\hline 7 & 33 & 66 & $33 \%$ & 35 & 70 & $35 \%$ & 43 & 86 & $3 \%$ \\
\hline 8 & 40 & 80 & $40 \%$ & 40 & 80 & $40 \%$ & 44 & 88 & $4 \%$ \\
\hline 9 & 34 & 68 & $34 \%$ & 38 & 76 & $38 \%$ & 46 & 92 & $6 \%$ \\
\hline Jumlah & & 674 & & & 730 & & & 806 & \\
\hline Rata-Rata & & 74,88 & & & 81,11 & & & 89,55 & \\
\hline Ketuntasan & & $33,33 \%$ & & & 66,66 & & & $100 \%$ & \\
\hline
\end{tabular}




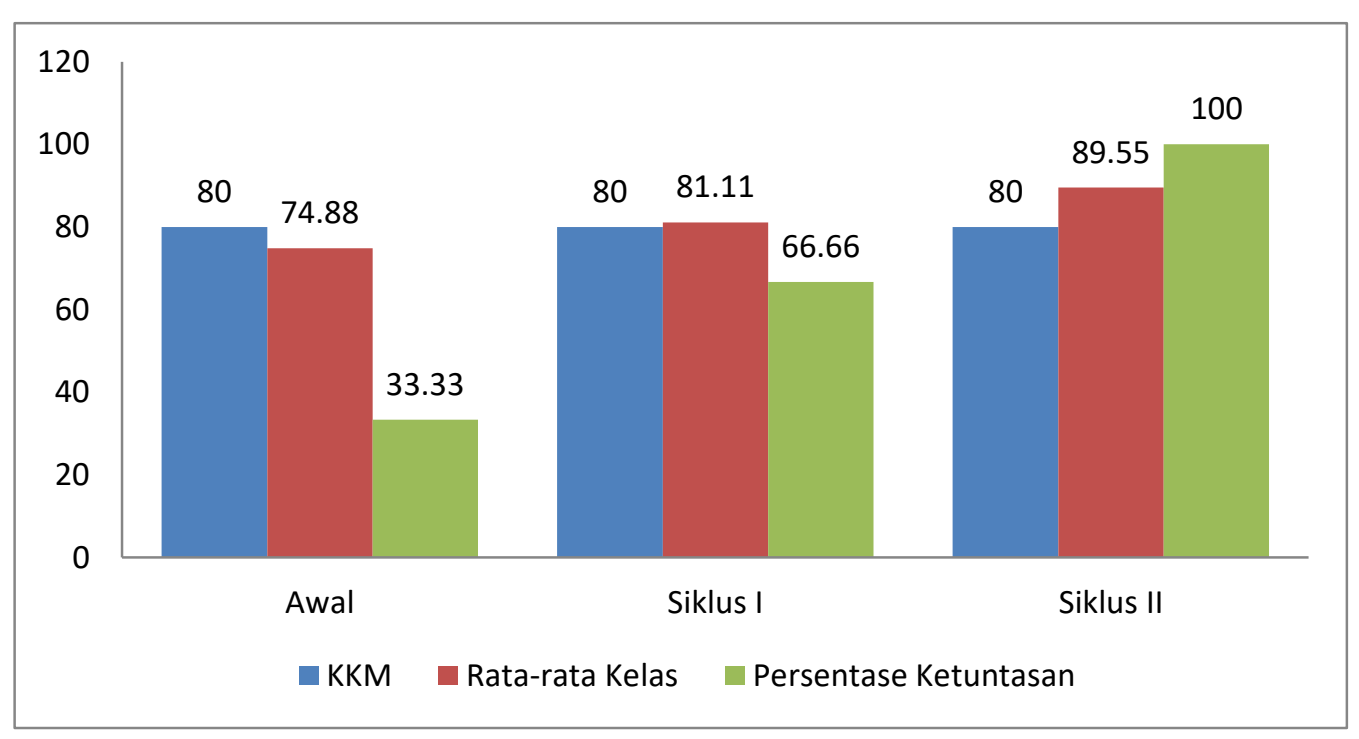

Gambar 1. Histogram Hasil Penelitian

Berdasarkan tabel dan gambar tersebut dapat deskripsi yang dapat disampaikan nuntuk perolehan data awal sebagai indikator yang dituntut yaitu minimal guru mampu mencapai ketuntasan belajar dengan nilai sama atau melebihi ketuntasan belum tercapai. Data yang diperoleh hanya 3 guru yang tuntas atau hanya 33,33\% yang tuntas dari 9 guru di SD Negeri 5 Bedulu pada semester I tahun pelajaran 2019/2020 dengan rata-rata 74,88. Data tersebut menunjukkan rendahnya kemampuan guru di SD Negeri 5 Bedulu dalam melaksanakan proses pembelajaran yang efektif. Kekurangan yang ada adalah akibat proses pembelajaran yang dilakukan oleh guru masih bersifat konvensional. Dari kemampuan guru awal dengan nilai rata-rata 74,88 dengan ketuntasan hanya mencapai 33,33\% akhirnya pada siklus I ini dapat ditingkatkan menjadi rata-rata 81,11 dengan ketuntasan meningkat menjadi $66,66 \%$. Upaya yang lebih giat yang bisa peneliti laksanakan pada siklus yang kedua ini penekanan pada perbaikanperbaikan dari kekurangan-kekurangan yang ada pada diri guru. Semua kekurangan pada siklus I yang sudah disampaikan pada refleksi siklus I di depan menjadi acuan bagi peneliti untuk melakukan perbaikan. Perbaikan ini banyak dilakukan pada pertemuan awal sebelum mereka masuk kelas. Pada saat bimbingan tersebut diberi penekanan agar mereka merubah cara yang mereka lakukan selama ini yaitu mengajar dirubah dengan membelajarkan. Jadi guru tidak diharapkan untuk menceramahkan materi, guru tidak diharapkan menghabiskan waktunya untuk berdiri di depan kelas dan ngomong a, b, c, dan dan terus menerus mendominasi kelas. Yang dituntut adalah lebih $60 \%$ waktu digunakan oleh siswa untuk memperoleh pengalaman belajar, jadi guru boleh duduk di bangku guru dan tidak harus terus menerus berdiri dan berceramah sampai waktu pembelajaran habis namun guru tetap juga berdiri. Pada pertemuan awal diberikan bimbingan tentang kekurangan-kekurangan yang ada selama siklus I untuk diperbaiki dan diminta agar guru-guru melihat apa yang mereka tulis di RPP dan melaksanakan sesuai apa yang mereka tulis. Disamping itu guru-guru juga diminta untuk memperhatikan waktu sesuai dengan apa yang mereka telah tulis di RPP. Diskusi yang matang yang dilakukan pada pertemuan awal ternyata mampu menghasilkan peningkatan yang cukup signifikan. Dari rata-rata siklus I adalah 81,11 dengan ketuntasan $66,66 \%$ pada siklus yang ke II naik menjadi 89,55 dengan ketuntasan mencapai $100 \%$. Keberhasilan ini tidak terlepas dari upaya yang sungguh-sungguh, upaya yang maksimal yang dapat ditujukan untuk peningkatan mutu pendidikan.

Kelebihannya adalah peneliti sebagai kepala sekolah telah giat melakukan supervisi secara maksimal. Pelaksanaan pembelajaran problem based instruction melalui kelompok kerja guru (KKG) telah diupayakan maksimal. Kendala yang ada adalah pada diri guru yang berlum terbiasa untuk melaksanakan pembelajaran menggunakan model pembelajaran problem based instruction mereka masih berpikir bahwa tugas mereka adalah mengajar dan belum betul-betul dimengerti bahwa sesuai aturan tugas mereka adalah membelajarkan. Kebiasaan ini masih muncul dan mendominasi pembelajaran pada siklus I. Guruguru pada siklus I ini masih tetap berdiri di depan kelas memperlihatkan diri kepala sekolah bahwa mereka adalah mengajar. Hal ini akhirnya dipecahkan dengan kembali berdiskusi dengan guru-guru, bertanya jawab baik pada saat pertemuan awal maupun pada saat dilakukan pertemuan balikan. Peneliti giat melakukan diskusi, memberi pengertian-pengertian pada mereka dalam upaya menstimulir kegiatan yang dilakukan guru demi adanya perbaikan sesuai arti supervisi. 
Dengan adanya model pembelajaran PBI melalui KKG proses pembelajaran yang dilakukan merubah paradigma guru tentang bagaimna proses pembejaran seharusnya. Model PBIini adalah salah satu model pembelajaran yang mampu mengatifkan sisiwa belajara. Meurut (Listiowati, 2013) Pembelajaran berbasis masalah atau Problem Based Instruction dikembangkan untuk membantu siswa mengembangkan kemampuan berpikir, pemecahan masalah, keterampilan intelektual, dan belajar berbagai peran dengan dewasa melalui pelibatan mereka dalam pengalaman nyata atau simulasi, serta menjadi siswa yang otonom dan mandiri. Menurut (Prayekti, 2010) Problem Based Instructional (PBI) menjadi alternatif model pembelajaran yang dapat diterapkan guru dalam pembelajaran fisika di kelas yang dapat meningkatkan hasil belajar, aktivitas dan respon siswa dalam pembelajaran. Menurut (Fujiah, 2016) Dengan penerapan model pembelajaran PBI siswa lebih memahami konsep yang diajarkan, sebab mereka sendiri yang menemukan konsep tersebut dan melibatkan secara aktif pemecahan masalah dan menuntut keterampilan berpikir siswa yang lebih tinggi.

Hal yang menjadi factor pengingkatan kemapuan guru dalam mengajar adalah suvervisi yang dilkukan oleha kepala sekolah denagan adanya bimbingan dan pengawasan kepala sekola membuat beban guru berkurang, karena jika terjadi maslah atau guru mengalami kesulitan maka guru akan ditemani dan dimbatu oleh kepala sekolah dalam menyelesaikan maslah yang diahadapi sampai pemecahan masalah dapat dipecahkan. (Pohan, 2017) menyatakan bahwa supervisi yang dilaksanakan kepala sekolah dapat meningkatkan pelaksanaan tugas pokok guru. Hal ini sejalan dengan pendapat yang disampaikan oleh metode pembelajaran dan teknik evaluasi pembelajaran yang dilakukan oleh kepala sekolah dapat memaksimalkan guru dalam bekerja (Auliya et al., 2012).

Hasil penelitian ini sejalan dengan hasil penelitian yang dilakukan oleh Yulidatullah, Silahuddin, dan Sadrina pada tahun 2018 dengan judul Penggunaan Metode Problem Based Instruction (PBI) Untuk Meningkatkan Hasil Belajar dan Motivasi Siswa Pada Materi Pengukuran Nilai Resistor Kelas X di SMK Negeri 1 Darul Kamal Aceh Besar. Pada penelitiannya dinyatakan bahwa: penggunaan metode pembelajaran PBI dapat meningkatkan motivasi belajar siswa pada materi "pengukuran nilai resistor" di kelas X Elektronika SMKN 1 Darul Kamal Aceh Besar. Selanjutnya penelitian yang dilakukan oleh Dewi, Singgih, dan Subiki pada tahun 2017 dengan judul Pengaruh Model Pembelajaran Problem Based Instruction disertai Metode Pictorial Riddle Terhadap Hasil Belajar Dan Kemampuan Berpikir Kritis Siswa Pada Mata Pelajaran Fisika di SMA. Berdasarkan hasil penelitian, maka dapat diambil kesimpulan sebagai berikut: (1) Model pembelajaran Problem Based Instruction disertai metode Pictorial Riddle pada mata pelajaran fisika berpengaruh signifikan terhadap hasil belajar siswa di SMA Negeri Arjasa. (2) Kemampuan berpikir kritis siswa SMA Negeri Arjasa dengan menggunakan model pembelajaran Problem Based Instruction disertai metode Pictorial Riddle pada mata pelajaran fisika bab usaha dan energi tingkat penguasaannya tergolong baik, dengan presentase rata-rata semua indikatornya adalah sebesar $64.91 \%$.

\section{Simpulan dan Saran}

Berdasarkan penelitian yang telah dilakukan dapat disimpulkan bahwa Model Pembelajaran Problem Based Instruction Melalui Kelompok Kerja Guru (KKG) secara efektif dapat Meningkatkan Kemampuan Guru Dalam Melaksanakan Pembelajaran Yang Efektif di SD Negeri 5 BEDULU Semester I Tahun Pelajaran 2019/2020.

Berdasarkan temuan yang sudah disimpulkan, juga dalam upaya peningkatan pendidikan secara khusus yang pada gilirannya nanti akan bermuara pada peningkatan mutu pendidikan, maka dapat disampaikan saran seperti berikut: 1) Dalam upaya meningkatkan kemampuan guru-guru melaksanakan proses pembelajaran perlu diupayakan cara tertentu yang tepat dalam pengobatannya. Salah satu contohnya adalah pembelajaran Problem Based Instruction (PBI). pendekatan pembelajaran Problem Based Instruction (PBI) memiliki banyak langkah-langkah yang bisa diupayakan mengingat pembelajaran Problem Based Instruction (PBI) adalah menstimulir kegiatan orang lain dalam upaya untuk perbaikan; 2) Bagi Dinas Pendidikan Kabupaten maupun Kota agar mengupayakan cara-cara yang khusus dalam memberi pengobatan pada guru-guru, salah satunya adalah menggunakan pembelajaran Problem Based Instruction (PBI) melalui Kelompok Kerja Guru (KKG); 3) Kelemahan yang ada selama penelitian adalah kurangnya buku-buku acuan yang disiapkan guru. Ada guru yang sama sekali tidak memiliki buku acuan tentang itu sehingga pada saat melakukan observasi, peneliti membawakan Permen-permen tentang Standar Proses, menyuruh agar mereka membaca sendiri, mencek unsur-unsur yang ada, landasanlandasan hukum, kategori-kategori yang ada dan lain-lain. Untuk ini saran yang bisa disampikan adalah agar guru-guru berusaha membeli sendiri buku-buku dan tidak menunggu uluran tangan dari pemerintah saja; 4) Bagi peneliti yang berminat untuk menverifikasi hasil penelitian yang sama walaupun tempatnya berbeda hendaknya mencoba melakukan penelitian yang sejenis sehingga dapat mengetahui kekurangan- 
kekurangan yang ada dan pada akhirnya dapat memberi saran masukan untuk perbaikan mutu penelitian di masa yang akan datang.

\section{Daftar Rujukan}

Auliya, U. U., Thomas, P., \& Lyna, L. (2012). Pengaruh Supervisi Kepala Sekolah Dan Motivasi Kerja Guru Terhadap Kinerja Guru. Economic Education Analysis Journal, 1(2). https://doaj.org/article/02685ed944d14a35b097327c4aca82a9

Departemen Pendidikan Nasional. 2009. Kompetensi Supervisi akademik. Jakarta: Dirjen Peningkatan Mutu Pendidik dan Tenaga Kependidikan.

Depdiknas. Departemen Pendidikan Nasional. 2008. Laporan Penelitian Tindakan Sekolah. Jakarta: Depdiknas.

Dewi, Dewa Ayu Desinta Ratna, Singgih Bektiarso, dan Subiki. 2017. Pengaruh Model Pembelajaran Problem Based Instruction disertai Metode Pictorial Riddle Terhadap Hasil Belajar Dan Kemampuan Berpikir Kritis Siswa Pada Mata Pelajaran Fisika di SMA. Jurnal Pembelajaran Fisika, Vol 6 No. 1, Maret 2017, hal 48-55.

Ekosiswoyo, R. (2016). Kepemimpinan Kepala Sekolah yang Efektif Kunci Pencapaian Kualitas Pendidikan. Jurnal Ilmu Pendidikan, 14(2), 76-82. https://doi.org/10.17977/jip.v14i2.24

Fujiah, Saiful Prayogi, \& Samsun Hidayat. 2016. Penerapan Model Pembelajaran Problem Based Instruction (PBI) Berbasis Autentik Asesment untuk Meningkatkan Kemampuan Berpikir Kritis Siswa. Jurnal Ilmiah Pendidikan Fisika "Lensa" Vol. 4 No.2, Hal. 55-58. Trsedia Pada: http://ojs.ikipmataram.ac.id/index.php/Lensa/article/view/84/82.

Khanafiyah, S., \& Yulianti, D. (2013). Model Problem Based Instruction Pada Mengembangkan Sikap Kepedulian Lingkungan. Jurnal Pendidikan Fisika Indonesia (Indonesian Journal of Physics Education), 9, 35-42. https://doi.org/https://doi.org/10.15294/jpfi.v9i1.2578

Komalasari, D., \& Program. (2019). Kefektifan Model Problem Based Instruction (Pbi) Dan Model Sinektik Dalam Pembelajaran Menulis Cerpen Siswa Sekolah Menengah Pertama. Jurnal Al-Ta'dib, 12(1). https://doi.org/http://dx.doi.org/10.31332/atdb.v12i1.1272

Lalu Muhammad. 1996. Supervisi Akademik. Surabaya: Penerbit Usaha Nasional.

Listiowati, Ayu Dwi, dan Antonius Tri Widodo. 2013. Penerapan Model Pembelajaran Problem Based Instruction dengan Pendekatan Predict-Observe-Explain. Jurnal Inovasi Pendidikan Kimia, Vol 7, No. 2, hlm. 1189-1200. Tersedia Pada: https://journal.unnes.ac.id/nju/index.php/JIPK/article/view/4419.

Margono, S. 1997. Metodologi Penelitian Pendidikan. Jakarta: Penerbit Rineka Cipta.

Muhani, M., Imron, A., \& Kusmintardjo, K. (2016). Kepemimpinan Kepala Sekolah Dasar Di Daerah Terpencil (Studi Multi Kasus Di Sdn 2 Bakalan Dan Sdn 2 Kepyar Purwantoro Kabupaten Wonogiri). Jurnal Pendidikan: Teori, Penelitian, Dan Pengembangan, 1(8), 1464-1472. https://doi.org/10.17977/JP.V1I8.6616

Pohan, N. (2017). Peran Supervisi Kepala Sekolah Terhadap Pelaksanaan Tugas Pokok Guru: Penelitian Tindakan Sekolah. JPD: Jurnal Pendidikan Dasar, 1(3), 132-139.

Prayekti. 2010. Problem Based Instruction sebagai alternatif Model Pembelajaran Fisika di SMA. Jurnal Pendidikan dan Kebudayaan, Vol. 16 No. 1, Hal. 51-63. Tersedia Pada: http://jurnaldikbud.kemdikbud.go.id/index.php/jpnk/article/view/431/287.

Ramadoni, W., \& Arifin, I. (2016). Kepemimpinan Kepala Sekolah Dalam Upaya Peningkatan Kinerja Guru (Studi Multi Kasus Di Paud Islam Sabilillah Dan Sdn Tanjungsari 1 Kabupaten Sidoarjo). 15001504Departemen Pendidikan Nasional. 2006. Manajemen Berbasis Sekolah. Jakarta: Depdiknas.

Suharsimi, Arikunto. 1992. Prosedur Penelitian. Jakarta: PT. Rineka Cipta. Azhar,

Yulidatullah, Silahuddin, dan Sadrina. 2018. Penggunaan Metode Problem Based Instruction (PBI) Untuk Meningkatkan Hasil Belajar dan Motivasi Siswa Pada Materi Pengukuran Nilai Resistor Kelas X di SMK Negeri 1 Darul Kamal Aceh Besar. Jurnal Ilmiah Pendidikan Teknik Elektro,Vol.2, No.1, Februari 2018, hal. 39-48. 